\title{
Soil Denitrification, the Missing Piece in the Puzzle of Nitrogen Budget in Lowland Agricultural Basins
}

\author{
Elisa Soana, ${ }^{1 *} \odot$ Fabio Vincenzi, ${ }^{1}$ Nicolò Colombani, ${ }^{2}{ }^{\circ}$ \\ Micòl Mastrocicco, ${ }^{3} \odot$ Elisa Anna Fano, ${ }^{1} \odot$ and Giuseppe Castaldelli ${ }^{1 *} \odot$
}

\begin{abstract}
${ }^{1}$ Department of Life Sciences and Biotechnology, University of Ferrara, Via L. Borsari 46, 44121 Ferrara, Italy; ${ }^{2}$ Department of Materials, Environmental Science and Urban Planning, Polytechnic University of Marche, Via Brecce Bianche 12, 60131 Ancona, Italy; ${ }^{3}$ Department of Environmental, Biological and Pharmaceutical Sciences and Technologies, Campania University "Luigi Vanvitelli", Via Vivaldi 43, 81100 Caserta, Italy
\end{abstract}

\begin{abstract}
Denitrification is a key process buffering the environmental impacts of agricultural nitrate loads but, at present, remains the least understood and poorly quantified sink in nitrogen budgets at the watershed scale. The present work deals with a comprehensive and detailed analysis of nitrogen sources and sinks in the Burana-Volano-Navigabile basin, the southernmost portion of the Po River valley (Northern Italy), an intensively cultivated ( $>85 \%$ of basin surface) low-lying landscape. Agricultural census data, extensive monitoring of surface-groundwater interactions, and laboratory experiments targeting $\mathrm{N}$ fluxes and pools were combined to provide reliable estimates of soil denitrification at the basin scale. In the agricultural
\end{abstract}

Received 1 December 2020; accepted 19 June 2021;

published online 19 July 2021

Supplementary Information: The online version contains supplementary material available at https://doi.org/10.1007/s10021-021-0067 6-y.

Author contributions ES: conceptualization, methodology, formal analysis, writing - original draft preparation, visualization. FV: investigation. NC: investigation, writing-review editing. MM: investigation, writing-review editing. EAF: funding acquisition. GC: conceptualization, methodology, writing-original draft preparation, funding acquisition, supervision.

*Corresponding author; e-mail: elisa.soana@unife.it; ctg@unife.it soils of the basin, nitrogen inputs exceeded outputs by nearly $40 \%\left(\sim 80 \mathrm{~kg} \mathrm{~N} \mathrm{ha}^{-1}\right.$ year $\left.^{-1}\right)$, but this condition of potential $\mathrm{N}$ excess did not translate into widespread nitrate pollution. The general scarcity of inorganic nitrogen species in groundwater and soils indicated limited leakage and storage. Multiple pieces of evidence supported that soil denitrification was the process that needed to be introduced in the budget to explain the fate of the missing nitrogen. Denitrification was likely boosted in the soils of the studied basin, prone to waterlogged conditions and consequently oxygen-limited, owing to peculiar features such as fine texture, low hydraulic conductivity, and shallow water table. The present study highlighted the substantial contribution of soil denitrification to balancing nitrogen inputs and outputs in agricultural lowland basins, a paramount ecosystem function preventing eutrophication phenomena.

Key words: Nitrogen budget; Watershed; Nitrate contamination; Soils; Canal network; Denitrification. 


\section{HighLIGHTS}

- A detailed $\mathrm{N}$ budget in soils and waters was calculated for a lowland coastal basin.

- $\mathrm{N}$ inputs in agricultural soils exceeded outputs by nearly $40 \%$.

- Waterlogged condition in fine-texture soils promoted $\mathrm{NO}_{3}{ }^{-}$removal via denitrification.

\section{INTRODUCTION}

In the last century, the intensification of agricultural activities has deeply altered the nitrogen $(\mathrm{N})$ budgets in the cropping systems of agriculturally dominated watersheds around the world. The $\mathrm{N}$ amount added to croplands through fertilization in excess to crop demand is lost to the environment, in particular, surface and groundwater, with multiple detrimental implications in terms of, for example, water quality deterioration, human health, and biodiversity loss (Erisman and others 2011; Houlton and others 2019). Nitrate $\left(\mathrm{NO}_{3}{ }^{-}\right)$ release from diffuse agricultural sources is still an unsolved environmental threat, a cause of eutrophication and groundwater pollution (Glibert and others 2006; Bodirsky and others 2014; Leip and others 2015).

Many questions on the fate of the missing $\mathrm{N}$ in agriculturally dominated basins remain open. For instance, about only $25 \%$, on average, of the $\mathrm{N}$ load generated within worldwide watersheds is delivered to terminal waterbodies and coastal zones via river export, but still little is known about the relative importance of different $\mathrm{N}$ retention mechanisms (Howarth and others 2012; Goyette and others 2016; Romero and others 2016). On this basis, questions on where and for how long $\mathrm{N}$ may accumulate in soils and aquifers and what transformations and removal processes it may undergo, preventing its export, are not yet properly addressed.

Heterotrophic denitrification, the microbial anaerobic respiration that reduces $\mathrm{NO}_{3}{ }^{-}$to dinitrogen gas $\left(\mathrm{N}_{2}\right)$, is globally considered the main biogeochemical reaction by which bioreactive $\mathrm{N}$ is lost to the atmosphere (Kulkarni and others 2008; Bouwman and others 2013). In aquifer systems, denitrification can occur also by oxidation of ironsulfur minerals such as pyrite (Bosch and others 2012; Jessen and others 2017). In fertilized finetextured soils, rainfall and poor drainage are expected to increase denitrification by decreasing oxygen availability and making the soil matrix more and more hypoxic and, thus, more prone to anaerobic respiration pathways (Hofstra and Bouwman 2005; Kuzyakov and Blagodatskaya 2015). Understanding if $\mathrm{NO}_{3}{ }^{-}$accumulates in the vadose zone or is permanently removed by denitrification (and where) is a key element for designing and implementing effective land use management strategies that protect water quality in agricultural basins (Wang and others 2017; Xin and others 2019; Kolbe and others 2019). In budgeting $\mathrm{N}$ in large agricultural areas, the main difficulty is to consider a multiplicity of $\mathrm{N}$ storages and sinks. Some terms, such as $\mathrm{NO}_{3}{ }^{-}$storage in the vadose zone (Ascott and others 2017; Van Meter and others 2016; Xin and others 2019) and artificial canal networks acting as $\mathrm{N}$ metabolic regulator in irrigated landscapes (Dollinger and others 2015; Soana and others 2019; Goeller and others 2020), have been assessed by an increasing number of studies in the last years, but their contribution to $\mathrm{N}$ removal at the watershed scale is case-specific. Moreover, heterogeneous conditions in terms of $\mathrm{N}$ fertilization practices (that is, type and dosage of fertilizers, application methods, and timing), hydrological processes, and soil types may result in an extreme increase of site-specificity, both in the generation and transformation of $\mathrm{N}$ loads. Denitrification in agricultural soils remains the least understood and poorly quantified sink in $\mathrm{N}$ budgets at the basin scale (Davidson and Seitzinger 2006; Almaraz and others 2019; De Girolamo and others 2019).

Conventional biogeochemical techniques (for example, acetylene inhibition method, ${ }^{15} \mathrm{~N}$ tracer methods) based on the incubation of intact soil cores, mesocosms, or slurries have long been adopted to measure soil denitrification and have contributed to the understanding of proximal drivers of the process, such as temperature, $\mathrm{NO}_{3}{ }^{-}$, and organic carbon availability (Barton and others 1999; Hofstra and Bouwman 2005; Chalk and others 2019). However, high uncertainty arises in extrapolating instantaneous point measurements to broader scales, as denitrification rates vary greatly in space and time, not only among different agroecosystems but also within the same parcel. Sampling and modeling approaches generally do not properly account for those small areas (hotspots) and brief periods (hot moments) that express the highest denitrification rates and remove a disproportionately high $\mathrm{NO}_{3}{ }^{-}$amount, causing a large underestimation of the overall denitrification relevance (Groffman and others 2009; Anderson and others 2014; Kuzyakov and Blagodatskaya 2015). On the other hand, modeling tools and geospatial 
approaches may also generate large overestimates when based on the upscaling of potential rates measured under optimal conditions of $\mathrm{NO}_{3}{ }^{-}$and organic carbon availability for denitrifying bacteria and not at all representative of in situ activity (Oehler and others 2009). Due to the complexity of field measurements, soil denitrification is rarely addressed as the main focus of research dealing with watershed $\mathrm{N}$ budgets. Nevertheless, where a huge amount of data (for example, high-resolution agricultural statistics, extensive monitoring of surface waters and aquifers, laboratory experiments targeting $\mathrm{N}$ fluxes and pools in soils, and so on) is available and the $\mathrm{N}$ inputs, outputs, and storages in croplands are accurately quantified, the mass balance approach may provide a reliable basin-level estimate of soil denitrification and a benchmark value to validate field measurements.

The present study aims at a better understanding of the watershed-scale importance of soil denitrification as a $\mathrm{NO}_{3}{ }^{-}$buffering mechanism in agricultural settings. A comprehensive and detailed analysis coupling $\mathrm{N}$ budget in the soil-shallow aquifer system and in surface waters allowed us to explain the fate of $\mathrm{N}$ excess by disentangling denitrification from groundwater storage and by also partitioning the contribution of soils and canal sediments in removing $\mathrm{NO}_{3}{ }^{-}$via denitrification.

The Burana-Volano-Navigabile basin, the southernmost portion of the Po River valley (Northern Italy), was selected as a case study for three main reasons: (1) the territory is intensively cropped and characterized by fine-textured soils; (2) the basin is completely flat and lies for the most part below the sea level and, thus, all water inputs and outputs are completely artificially managed and regularly monitored, allowing accurate water and $\mathrm{N}$ budgets in the canal network; (3) extensive information is available on hydrogeological drivers and bacterial processes controlling $\mathrm{N}$ transformations and horizontal and vertical migration paths. Soil features regulating $\mathrm{NO}_{3}{ }^{-}$removal have been deeply investigated in laboratory-controlled experiments (Castaldelli and others 2019; Mastrocicco and others 2019a), and preliminary estimates of basin-scale soil denitrification rates were obtained in the deltaic portion of the Po River Basin through a detailed investigation about $\mathrm{N}$ sources and sinks in the croplands (Castaldelli and others 2020). A comprehensive and quantitative understanding of denitrification in the context of $\mathrm{N}$ fluxes at the basin scale is still lacking, and there is an urgent need to integrate all the acquired findings to shed light on this still missing pathway of the $\mathrm{N}$ cycle in agriculturally dominated landscapes. The main novelty of this work is to present a basin-level estimate of soil denitrification to gain insight into its relevance as a nitrate buffering mechanism where agriculture deeply affects watershed $\mathrm{N}$ budgets.

\section{Materials AND Methods}

\section{Study Area}

The Burana-Volano-Navigabile watershed $\left(\sim 2600 \mathrm{~km}^{2}\right.$, Figure 1$)$ is a deltaic territory, recently reclaimed and intensively cropped, approximately overlapping the administrative borders of the Ferrara Province (Emilia-Romagna Region, Northeastern Italy). This basin is the terminal portion of the Po River Basin (Figure la, b), the largest hydrographic system in Italy and one of the most agriculturally exploited and densely populated areas in Europe. Here, eutrophication and $\mathrm{NO}_{3}{ }^{-}$ pollution of surface and groundwater are serious environmental issues (Viaroli and others 2018; Martinelli and others 2018; Malagó and others 2019; Musacchio and others 2020). The BuranaVolano-Navigabile watershed covers an area extending from the city of Ferrara to the Adriatic Sea and is limited to the north by the Po River main course and to the south by the Reno River. The climate is warm temperate (Type Cfa, according to Köppen-Geiger classification, Beck and others 2018) with a mean wet deposition of about $600 \mathrm{~mm} \mathrm{year}^{-1}$ over the last 20 years (data from seven weather stations belonging to the official monitoring network of the Hydro-Meteorological Service of the Environmental Protection Agency, Emilia-Romagna Region; https://simc.arpae.it/dex t3r/). According to the World Reference Base for Soil Resources classification (IUSS Working Group WRB 2006), the soil textures are: silty-loam (42\% of the basin area), silty-clay $(26 \%)$, peat $(23 \%)$, and sand $(9 \%)$.

More than $85 \%$ of the basin surface is devoted to agriculture (that is, utilized agricultural areaUAA), fertilized almost exclusively with synthetic urea and ammonium nitrate, and about $10 \%$ is classified as artificial area with a spread urban planning scheme characterized by low population density (Figure 1d). Cereals are the main crops, covering more than half of the agricultural land (wheat, maize, and rice, $30 \%, 21 \%$, and $4 \%$ of the UAA, respectively), followed by industrial and horticultural crops $(22 \%)$ and feed crops, mostly alfalfa $(10 \%)$, and fruit trees $(9 \%)$. Animal husbandry consists of poultry $\left(1.4 \times 10^{6}\right)$, pigs $(\sim 48,000)$, and cattle $(\sim 22,000)$, resulting in 


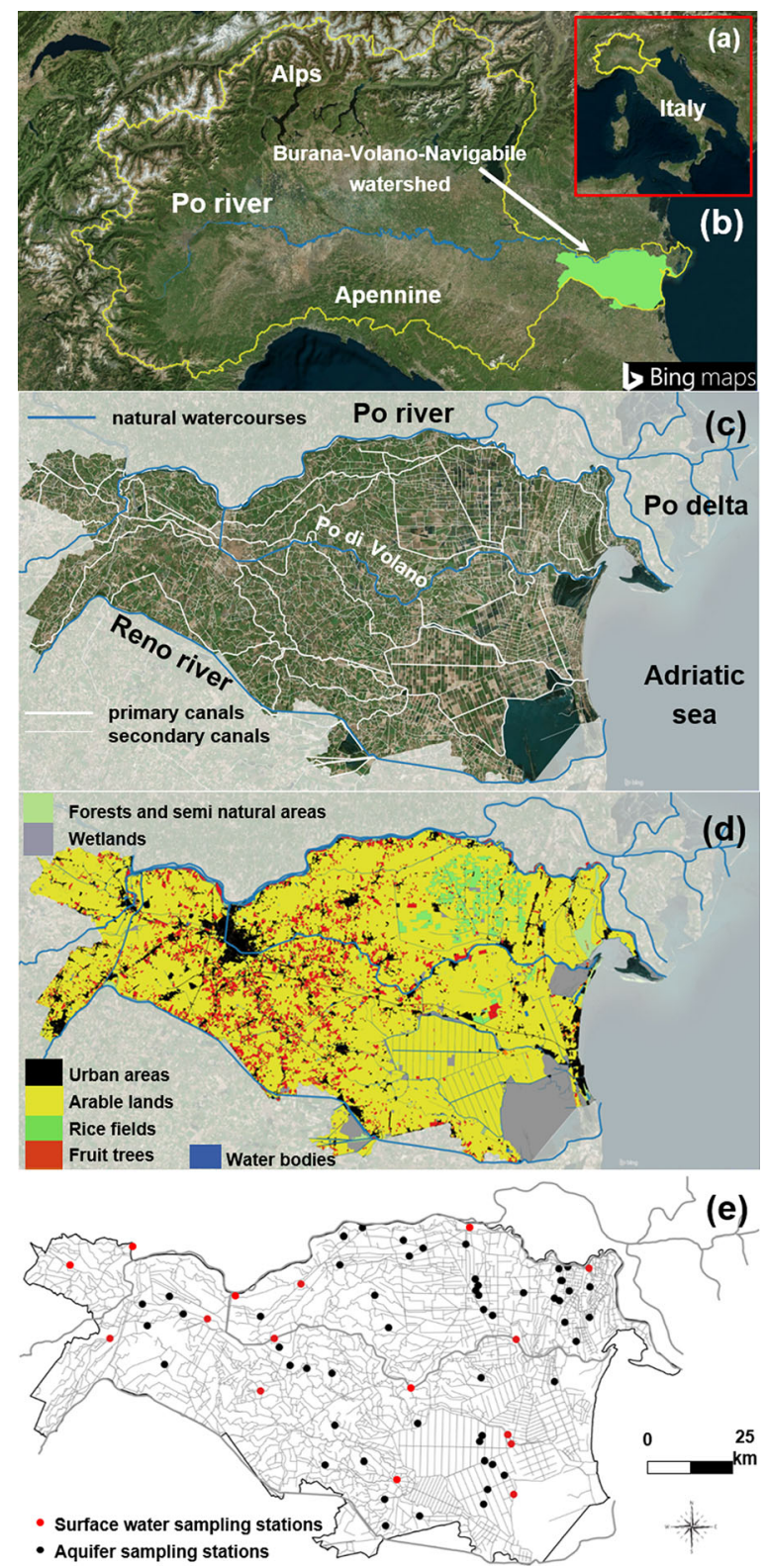

Figure 1. Study area: (a) location of the Po River Basin in Italy, (b) location of the Burana-Volano-Navigabile watershed within the Po River Basin, (c) land use/land cover map, (d) hydrological network (source of vector data: Emilia-Romagna Region geoportal, http://geoporta le.regione.emilia-romagna.it/it; on-line Bing Aerial map background, Baselayer for QGIS), and (e) location of the sampling stations.

$<0.5$ livestock unit-equivalent to an adult dairy cow-per ha of UAA (National Statistics Institution, 6th Agricultural Census 2010; http://dati-censime ntoagricoltura.istat.it). The whole Burana-VolanoNavigabile watershed was declared a Nitrate Vulnerable Zone (NVZ) from agricultural sources, in accordance with the European Nitrates Directive
(91/676/EEC) and the NVZ Action Plan of the Emilia-Romagna Region.

This basin lies in a depressed area for the most part below the sea level (on average, $2 \mathrm{~m}$ a.s.l.); thus, the hydrological regime is artificially regulated by a capillary network of canals, pumping stations, and gates. Irrigation water (500$2500 \times 10^{3} \mathrm{~m}^{3}$ day $^{-1}$ from April to September) is derived from the Po River and feeds several openearth canals surrounding fields (linear extension of $3965 \mathrm{~km}$, Figure 1c). The main irrigation systems through which the Po River water is supplied to the agricultural activities are aspersion and microirrigation, used in $51 \%$ and $21 \%$ of the irrigated surface, respectively (National Statistics Institution, 6th Agricultural Census 2010; http://dati-censime ntoagricoltura.istat.it). Excess water is drained from the fields and discharged through some major collectors into the Po di Volano, an ancient branch of the Po River Delta at present canalized (Cencini 1999). The shallow unconfined aquifer, whose thickness ranges between 2 and $7 \mathrm{~m}$, is fed by both rain infiltration and surface water system; thus, the water table usually fluctuates between 0.5 and $2.0 \mathrm{~m}$ from the ground surface (Mastrocicco and others 2017).

\section{Calculation of N Budget in Soils}

The $\mathrm{N}$ budget in soils was compiled for the 5-year period 2006-2010 by employing statistical data on agricultural activities and experimental measurements in soils and waters (that is, field monitoring campaigns and laboratory experiments) collected thanks to several research projects performed in the Burana-Volano-Navigabile watershed. $\mathrm{N}$ inputs and outputs across the UAA were computed according to the methodology developed by Castaldelli and others (2020) and previously tested and applied in a portion of the Po River Delta. The $\mathrm{N}$ budget approach adopted here got its robustness from the use of high-spatial-resolution datasets (for example, crop areas, livestock densities), sitespecific agronomic coefficients (for example, cropspecific fertilizer recommendations, crop yields), and $\mathrm{N}$ cycling measurements gathered from the study area (for example, ammonia volatilization rates, rainfall $\mathrm{N}$ content). Official agricultural census data, the basis for all agriculture regulations in Italy, were provided by local (Ferrara Province, Agriculture Department) and national (National Statistics Institution) statistical authorities. Moreover, for the study area, statistical data and agronomic coefficients used to compile the budget were checked and validated by a panel of 30 agronomists 
who worked as Ferrara Province consultants in the framework of the EC project EU-WATER ("Transnational integrated management of water resources in agriculture for the European WATER emergency control," contract n. SEE/A/165/2.1/X; http://www.eu-water.eu/).

$\mathrm{N}$ inputs and outputs were first calculated for each of the 26 municipalities (surfaces from 16 to $440 \mathrm{~km}^{2}$ ) including the Burana-Volano-Navigabile watershed and then aggregated at the basin scale. According to the official EU division for regional statistics elaborated by EUROSTAT (2015), Italian municipalities correspond to the LAU-2 territorial level, Italian provinces to the NUTS-3 territorial level, and Italian regions to the NUTS-2 territorial level. Municipality is the smallest administrative unit at which official agricultural and demographic statistics are usually available for the whole national territory and also the scale at which the Nitrates Directive restrictions are applied.

The $\mathrm{N}$ budget in soils was calculated as follows:

$$
\begin{aligned}
& \text { Man + Synth + Fix + Dep } \\
& \quad=\text { Harv }+ \text { Vol }+ \text { Runoff }+ \text { Den }(s)
\end{aligned}
$$

where Man $=\mathrm{N}$ in livestock manure applied to UAA, Synth $=\mathrm{N}$ in synthetic $\mathrm{N}$ fertilizers applied to UAA, Fix $=\mathrm{N}$ from biological fixation, Dep $=\mathrm{N}$ deposition on UAA, Harv = N exported from UAA by crop harvest, $\mathrm{Vol}=\mathrm{N}$ lost to the atmosphere by ammonia $\left(\mathrm{NH}_{3}\right)$ volatilization, Runoff $=\mathrm{N}$ lost from agricultural soils to surface water via runoff, and $\operatorname{Den}(\mathrm{s})=$ denitrification in soils

A detailed description of data sources, budget equations, and uncertainty assessment is reported in Supplementary Materials 1. A Microsoft Excel spreadsheet containing the formulae for the computation of each budget term of Eq. 1 was employed. $\mathrm{N}$ inputs and outputs were spatialized at the municipality level by GIS analysis (QGIS software 2.18, https://www.qgis.org/it/site/).

$\mathrm{N}$ lost from agricultural soils to surface water via runoff (Runoff) was estimated by difference after all the other terms of the $\mathrm{N}$ budget in the canal network were quantified according to Eq. (2), as detailed in the following paragraph. The unaccounted complement of the balance in soils, that is, the difference between input and other loss terms was assumed to be ascribed to denitrification (Den(s)). This assumption was supported by the provision of data proving a general scarcity of mineral $\mathrm{N}$ forms in both shallow aquifers and soils. The outcomes from the extensive monitoring of the shallow aquifer were integrated with those obtained by previous repeated analytical campaigns in surficial soils of the investigated basin (Castaldelli and others 2013a; Mastrocicco and others 2019b) to assess the magnitude of $\mathrm{N}$-reactive forms' availability in the vadose zone.

Spatiotemporal nitrate contamination in the shallow aquifer was assessed by analyzing the outcomes from a 2-year sampling campaign. A network of 56 monitoring wells was installed throughout the agricultural land of the BuranaVolano-Navigabile watershed covering the predominant soil textures and main crop (Figure le). The monitoring wells screens $(20 \mathrm{~cm}$ long) were located just below the shallow water table (on average, at $2 \mathrm{~m}$ below ground level) to capture the recharge water pulses that reached the aquifer. Sampling campaigns were performed almost monthly in 2010 and 2011 to evaluate $\mathrm{N}$ species distributions in the shallow unconfined aquifer. After purging at least two times the well volume, water samples were collected using an inertial pump, filtered in situ through $0.22 \mu \mathrm{m}$ polypropylene filters and stored at $4{ }^{\circ} \mathrm{C}$ during the transport to the laboratory. Here, samples were analyzed for $\mathrm{NO}_{3}{ }^{-}$using Technicon AutoAnalyser II (Armstrong and others 1967).

\section{Calculation of N Budget in the Canal Network}

The $\mathrm{N}$ budget in the canal network was compiled by employing statistical data on population and industrial activities and field observations collected in the 5-year period 2006-2010. According to the methodology developed by Castaldelli and others (2020), the following equation was used:

$$
\begin{aligned}
& \text { Inflow }+ \text { Urb }+ \text { Dep_Urb + Ind + Runoff } \\
& \quad=\text { Outflow }+ \text { Den }(c),
\end{aligned}
$$

where Inflow $=\mathrm{N}$ load imported in the watershed by the canal network, Urb $=\mathrm{N}$ load generated in urban areas, Dep_Urb $=\mathrm{N}$ deposition on surfaces other than agricultural land (that is urban and industrial areas), Ind $=\mathrm{N}$ load generated in industrial areas, Runoff $=\mathrm{N}$ lost from agricultural soils to surface water via runoff, Outflow $=\mathrm{N}$ load exported from the watershed by the canal network, and $\operatorname{Den}(\mathrm{c})=\mathrm{N}$ removed in the canal sediments by denitrification.

A description of the calculation of $\mathrm{N}$ budget in the canal network is detailed in Supplementary Materials 1. 


\section{ReSUlts}

\section{N Budget in Soils}

Within the 5-year period 2006-2010, the $\mathrm{N}$ budget in the agroecosystems of the Burana-Volano-Navigabile watershed evidenced that synthetic fertilizers were the main contribution to all the $\mathrm{N}$ imported to agricultural soils in the basin, averaging at $68 \%$ of total $\mathrm{N}$ inputs, followed by biological fixation $(23 \%)$, livestock manure $(6 \%)$, and atmospheric deposition (3\%) (Table 1). The proportion among the $\mathrm{N}$ input terms at the watershed scale reflected what was evidenced at the municipal level, with synthetic fertilizers being always the most relevant $\mathrm{N}$ source in all the municipalities (range 103-180 $\mathrm{kg} \mathrm{N} \mathrm{ha}^{-1}$ year $^{-1}$ ), while biological fixation and livestock manure reached maximum values of 130 and $61 \mathrm{~kg} \mathrm{~N} \mathrm{ha}^{-1}$ year $^{-1}$, respectively. $\mathrm{N}$ from livestock manure was produced mainly by poultry breeding $(43 \%)$, followed by cattle breeding $(37 \%)$. Alfalfa contributed almost two-thirds of the total $\mathrm{N}$ input from biological fixation (Table 1). Total $\mathrm{N}$ input in the municipalities of the studied area varied from 163 to $274 \mathrm{~kg} \mathrm{~N} \mathrm{ha}^{-1}$ year $^{-1}$ (Figure S4, Supplementary Materials 2), with an average value of $205 \mathrm{~kg} \mathrm{~N} \mathrm{ha}^{-1}$ year $^{-1}$ at the basin scale (Table 1). $\mathrm{N}$ export via crop harvest was the main output from soils among the three terms included in the budget, accounting for about $97 \%$ of the sum of all items (Table 1). Amount of $\mathrm{N}$ removed from soils with crop harvest (municipal values ranging from 103 to $160 \mathrm{~kg} \mathrm{~N} \mathrm{ha}^{-1}$ year $^{-1}$ ) was two orders of magnitude higher than that removed through other loss pathways, that is, runoff and $\mathrm{NH}_{3}$ volatilization. Two cereals (maize and wheat) accounted for more than $50 \%$ of the total $\mathrm{N}$ removed in crop biomass from cultivated land. Total $\mathrm{N}$ output in the municipalities of the studied area varied from 104 to $163 \mathrm{~kg} \mathrm{~N} \mathrm{ha}^{-1}$ year $^{-1}$ (Figure S4, Supplementary Materials 2), with an average value of $123 \mathrm{~kg} \mathrm{~N} \mathrm{ha}^{-1}$ year $^{-1}$ at the basin scale (Table 1).

Table 1. Nitrogen Budget in the Soils of the Burana-Volano-Navigabile Watershed.

\begin{tabular}{|c|c|c|}
\hline \multirow[t]{2}{*}{ Volano-Burana watershed } & \multicolumn{2}{|l|}{$\mathrm{N}$ budget } \\
\hline & t $N$ year $^{-1}$ & kg N ha ${ }^{-1}$ year $^{-1}$ \\
\hline \multicolumn{3}{|l|}{ INPUT } \\
\hline $\begin{array}{l}\text { Livestock manure } \\
\text { Poultry: } 43 \% \\
\text { Cattle: } 37 \% \\
\text { Pigs: } 16 \% \\
\text { Other: } 4 \%\end{array}$ & $2324 \pm 902$ & $13 \pm 5$ \\
\hline Synthetic inorganic fertilizers & $25,432 \pm 2613$ & $139 \pm 14$ \\
\hline $\begin{array}{l}\text { Biological fixation } \\
\text { Alfalfa: } 64 \% \\
\text { Soybean: } 19 \% \\
\text { Other: } 17 \%\end{array}$ & $8631 \pm 1936$ & $47 \pm 11$ \\
\hline Atmospheric deposition & $1131 \pm 790$ & $6 \pm 4$ \\
\hline$\Sigma$ input & $37,519 \pm 3466$ & $205 \pm 19$ \\
\hline \multicolumn{3}{|l|}{ OUTPUT } \\
\hline $\begin{array}{l}\text { Crop harvest } \\
\text { Wheat: } 27 \% \\
\text { Maize: } 26 \% \\
\text { N-fixing crops: } 23 \% \\
\text { Industrial crops: } 6 \% \\
\text { Horticultural crops: } 9 \% \\
\text { Other crops: } 9 \%\end{array}$ & $22,006 \pm 4932$ & $120 \pm 27$ \\
\hline $\mathrm{NH}_{3}$ volatilization & $564 \pm 462$ & $3 \pm 2$ \\
\hline $\mathrm{N}$ lost in runoff water & $61 \pm 31$ & $1 \pm 0.5$ \\
\hline$\Sigma$ output & $22,632 \pm 4954$ & $124 \pm 27$ \\
\hline$\Sigma$ input-- $\Sigma$ output & $14,887 \pm 6046$ & $81 \pm 33$ \\
\hline
\end{tabular}

Budget items are reported as average \pm standard deviation of the 5-year period 2006-2010 and expressed as tons of $N$ imported or exported per year ( $N$ year ${ }^{-1}$ ) in the whole area and normalized for the utilized agricultural area $\left(\mathrm{kg} \mathrm{N} \mathrm{ha}^{-1} \mathrm{year}^{-1}\right)$. 
After accurately accounting for all the budget terms, however, inputs $\left(\sim 37,500 \mathrm{t} \mathrm{N}\right.$ year $\left.^{-1}\right)$ exceeded outputs $\left(\sim 22,600 \mathrm{t} \mathrm{N}_{\mathrm{N}} \mathrm{yer}^{-1}\right)$ by about $40 \%$ (Table 1). At the basin scale, the average unaccounted term was $81 \mathrm{~kg} \mathrm{~N}^{-1}$ year $^{-1}$, with municipal values ranging from 47 to $128 \mathrm{~kg} \mathrm{~N}^{-}$ ${ }^{1}$ year $^{-1}$ (Figure S4, Supplementary Materials 2).

\section{Nitrate Concentrations in Surface Waters and Shallow Aquifer}

During the investigated 5-year period, $\mathrm{NO}_{3}{ }^{-}$concentrations of the water volumes entering the canal network displayed a marked seasonal variation (Figure 2a), with the highest values recorded in the middle of the winter (January, median value $3.7 \mathrm{mg} \mathrm{N} \mathrm{L}^{-1}$ ) and minimum values in the middle of the summer (July, median value $1.3 \mathrm{mg} \mathrm{N} \mathrm{L}^{-1}$ ). Nitrate decreased constantly from January to July, with values that more than halved along the first 7 months of the year and then increased again in the second part of the year. Median $\mathrm{NO}_{3}{ }^{-}$concentrations of the water volumes exiting the canal network remained in the range $2.0-3.0 \mathrm{mg} \mathrm{N} \mathrm{L}^{-1}$ from January to April and showed values constantly lower than $1 \mathrm{mg} \mathrm{N} \mathrm{L}^{-1}$ from June to October, before increased again starting from the middle of the autumn (Figure $2 \mathrm{~b}$ ). For each month, $\mathrm{NO}_{3}{ }^{-}$concentrations of the water exiting the basin were systematically lower, despite the higher variability, than those conveyed by the Po River water imported into the canal network (Figure 2a, b), up to over $75 \%$ in the late summer.

During the whole monitoring period, $\mathrm{NO}_{3}{ }^{-}$ concentrations in the shallow aquifer were generally much lower than those measured in surface waters and without any clear seasonal trend: median monthly values never exceeded $0.2 \mathrm{mg} \mathrm{N} \mathrm{L} \mathrm{L}^{-1}$, and only in some transient occasions did $\mathrm{NO}_{3}{ }^{-}$concentrations peak at $4-7 \mathrm{mg} \mathrm{N} \mathrm{L}^{-1}$ (Figure 2c). In all sites and months, $\mathrm{NO}_{3}{ }^{-}$was constantly below the limit of $11.3 \mathrm{mg} \mathrm{N} \mathrm{L}^{-1}$, the maximum permissible concentration in drinking water according to the World Health Organization (WHO 2004). The concentrations were quite homogeneous at the spatial scale, with only a few hotspots in correspondence to groundwater samples belonging to sandy soils (that is, Po River paleo-channels and coastal paleo-dunes) (Figure 3).

\section{$\mathrm{N}$ Budget in the Canal Network}

The canal network imported annually about $550 \mathrm{t}$ $\mathrm{N}$ via irrigation waters, with monthly $\mathrm{N}$ loads ranging from minimum values in late autumn-

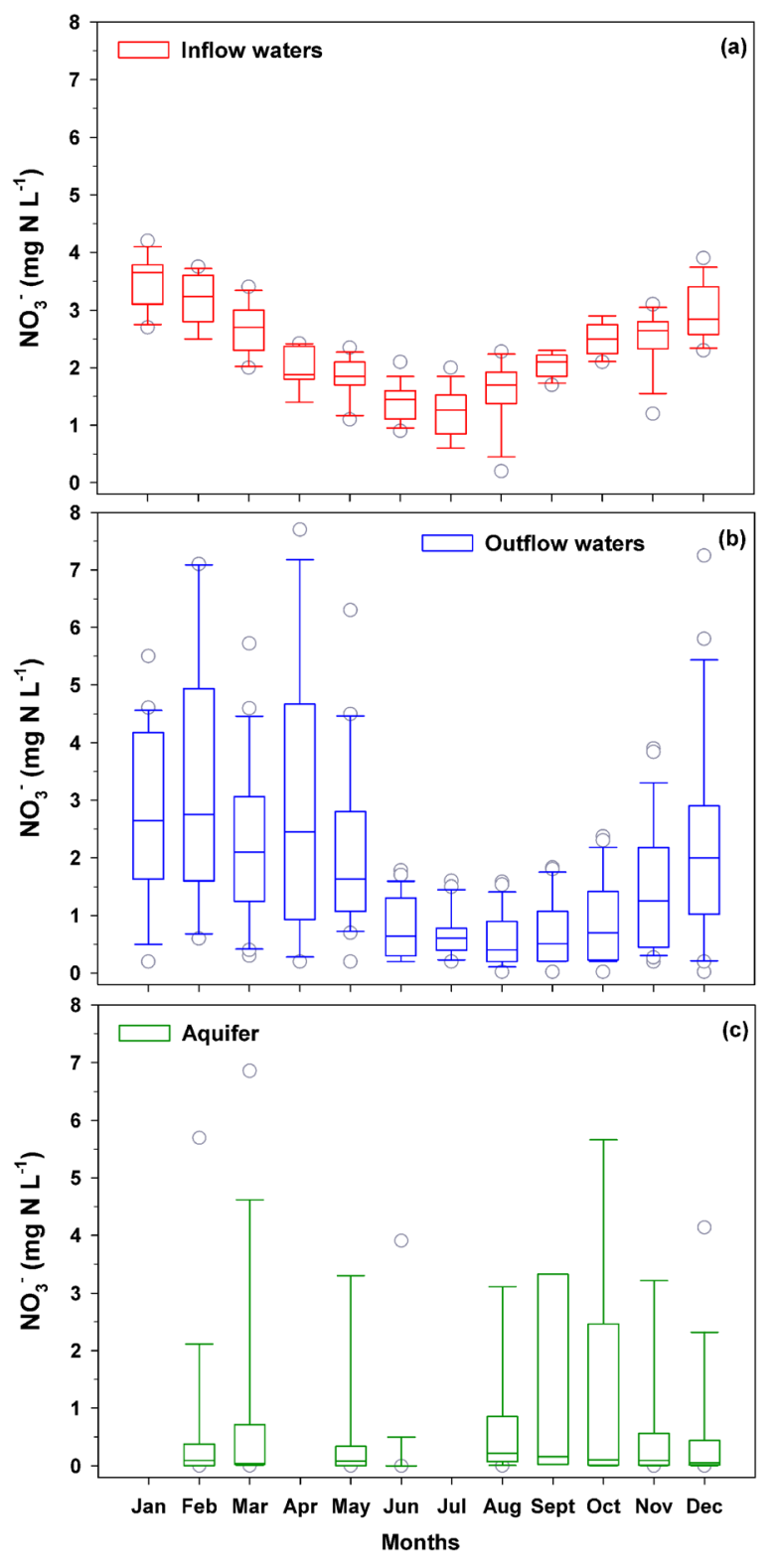

Figure 2. Temporal pattern of nitrate concentrations in water imported and exported by the canal network and in the aquifer of the Burana-Volano-Navigabile watershed. Central horizontal line in the box is the median, top and bottom boxes are 25th and 75 th percentiles, and whiskers are 10th and 90th percentiles. Outliers are shown as open circles.

winter period $\left(<10 \mathrm{t} \mathrm{N}\right.$ month $\left.^{-1}\right)$ to maximum values in late spring-summer period (up to $117 \mathrm{t} \mathrm{N} \mathrm{month}^{-1}$ in July) (Figure 4). Monthly $\mathrm{N}$ loads exported from the basin followed an inverse seasonal pattern with summer minima (18$35 \mathrm{t} \mathrm{N} \mathrm{month}^{-1}$ ) and winter peaks (up to $186 \mathrm{t} \mathrm{N} \mathrm{month}^{-1}$ in December) for a total of about $1000 \mathrm{t} \mathrm{N}$ reaching annually the coastal area via drainage waters. The canal network acted as an $\mathrm{N}$ 


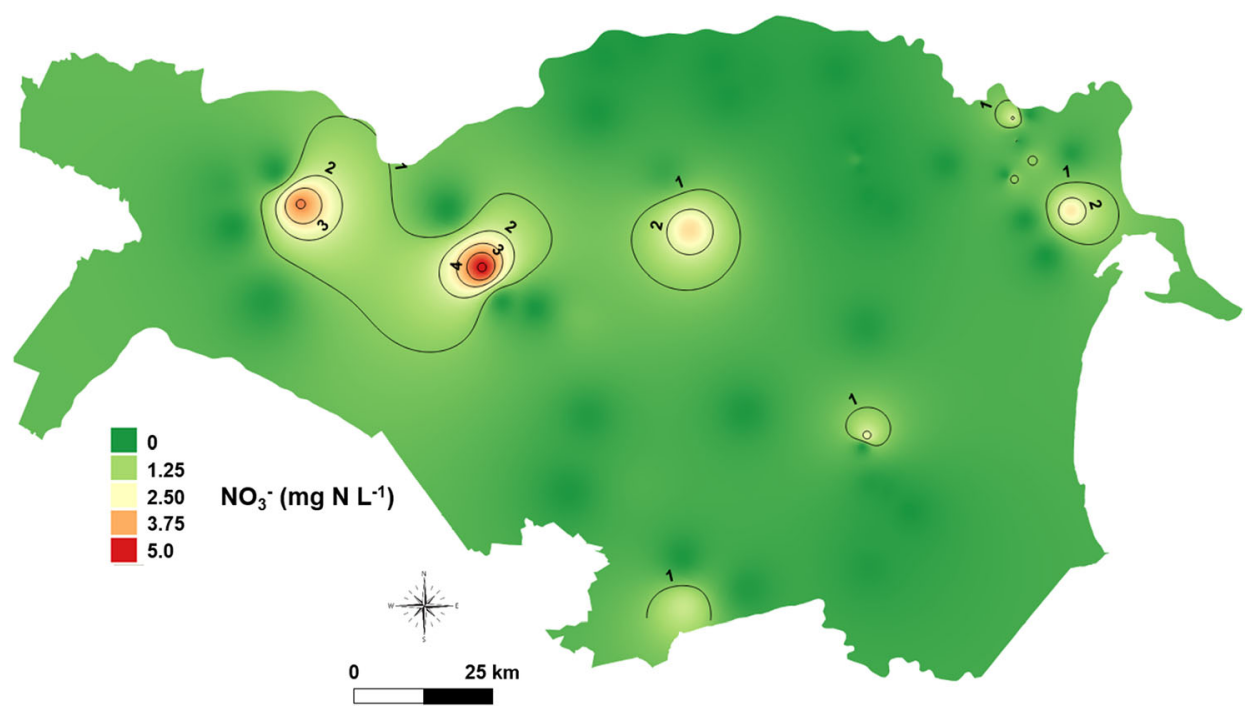

Figure 3. Median nitrate concentrations (years 2010-2011) in the shallow unconfined aquifer of the Burana-VolanoNavigabile watershed.

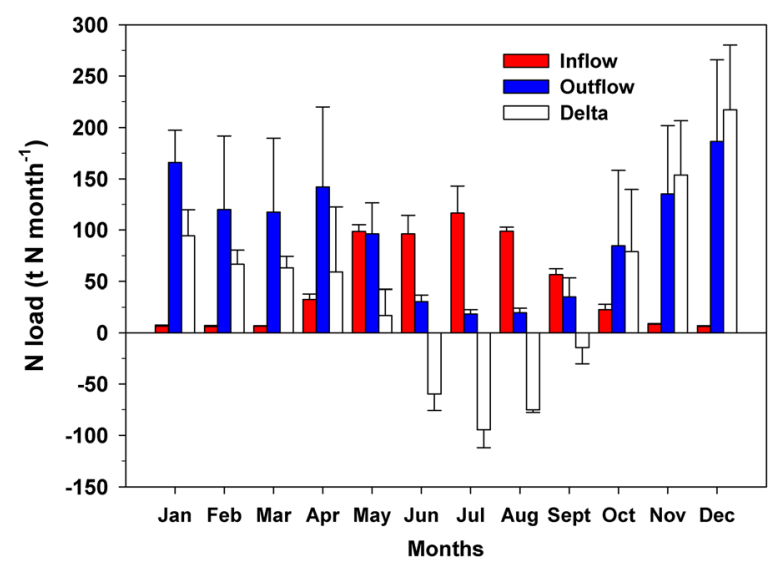

Figure 4. Temporal pattern of monthly $\mathrm{N}$ loads $\left(\mathrm{NO}_{3}{ }^{-}+\mathrm{NO}_{2}{ }^{-}+\mathrm{NH}_{4}{ }^{+}\right)$, reported as inflow, outflow, and their difference, in the canal network of the Burana-Volano-Navigabile watershed (average \pm standard deviation of the 5-year period 2006-2010).

sink throughout the summer months (from June to September), with a net decrease between imported and exported $\mathrm{N}$ loads ranging from 15 to $95 \mathrm{t} \mathrm{N}$ month $^{-1}$ (Figure 4). During the whole summer, $\mathrm{N}$ loads reaching the coastal area were lower by $38-85 \%$ than those imported into the canal network and from upstream ecosystems. In contrast, during the rest of the year, monthly $\mathrm{N}$ loads exported by the canal network were 4 to almost 30 times greater than the corresponding imported $\mathrm{N}$ loads, with the maximum increase detected in winter.
$\mathrm{N}$ removal via denitrification in the canal network of the basin was estimated as $740 \mathrm{t} \mathrm{N}$ year $^{-1}$ (Figure 5) of which about $73 \%$ occurred from April to September when the canals were active for irrigation. Vegetated canals accounted for only a minor fraction $(7-11 \%)$ of the total removal for the months from April to June when the emergent vegetation can develop prior to mowing operations carried out by the local water management authority. The highest monthly $\mathrm{N}$ removal rates via denitrification in the canal network were estimated in the spring-summer period $\left(68-125 \mathrm{t} \mathrm{N}\right.$ month $^{-}$ $\left.{ }^{1}\right)$ when also the maximum monthly differences

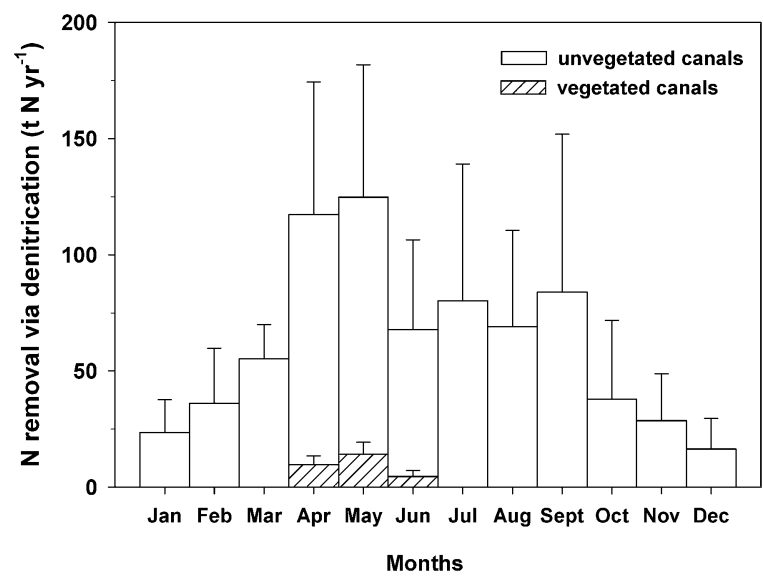

Figure 5. Monthly $\mathrm{N}$ removal via denitrification in the canal network of the Burana-Volano-Navigabile watershed (average \pm standard deviation of the 5-year period 2006-2010). Each monthly value is split into the contribution of vegetated and unvegetated canals. 
between imported and exported $\mathrm{N}$ loads were recorded (Figures 4, 5).

$\mathrm{N}$ loads generated in urban and industrial areas and discharged into the canal network were estimated as about $570 \mathrm{t} \mathrm{N}$ year $^{-1}(\sim 334,000$ inhabitants) and about $200 \mathrm{t} \mathrm{N}$ year $^{-1}$, respectively (Figure 6). $\mathrm{N}$ load imported from upstream ecosystems and $\mathrm{N}$ loads generated in urban areas were the two main inputs in the budget in the canal network and contributed almost equally (overall $65 \%$ ), followed by $\mathrm{N}$ deposition on surfaces other than agricultural soils $(24 \%), \mathrm{N}$ load from industrial areas $(8 \%)$, and runoff $(3 \%)$. Point $\mathrm{N}$ loads generated in urban and industrial areas $\left(\sim 1100 \mathrm{t} \mathrm{N}^{\mathrm{Near}}{ }^{-1}\right)$ corresponded as a whole to less than $3 \%$ of the diffuse $\mathrm{N}$ loads from agricultural activities (that is, total $\mathrm{N}$ input to agricultural soils, $\sim 37,500 \mathrm{t} \mathrm{N} \mathrm{year}^{-1}$ ) (Figure 6).

\section{Discussion}

The detailed $\mathrm{N}$ budget in the agroecosystems and canal network of the Burana-Volano-Navigabile watershed showed that: (1) $\mathrm{N}$ inputs in agricultural soils exceeded outputs by nearly $40 \%$ (that is, on average $\sim 80 \mathrm{~kg} \mathrm{~N} \mathrm{ha}^{-1}$ year $^{-1}$ ); (2) $\mathrm{N}$ runoff to surface waters accounted for less than $1 \%$ of the total $\mathrm{N}$ input to soils; (3) even though the magnitude of $\mathrm{N}$ input to soils was very large, $\mathrm{NO}_{3}{ }^{-}$concentrations recorded in the shallow aquifer of the whole watershed were steadily very low; (4) canal network acted as a net $\mathrm{NO}_{3}{ }^{-}$sink during the spring-summer months by attenuating the $\mathrm{N}$ load imported with irrigation water; and (5) denitrification in soils was likely the process responsible for balancing $\mathrm{N}$ inputs and outputs.

\section{$\mathrm{N}$ Budget in the Agroecosystems of the Burana-Volano-Navigabile Watershed}

The areal $\mathrm{N}$ input through fertilization in the Burana-Volano-Navigabile watershed (range 163$274 \mathrm{~kg} \mathrm{~N} \mathrm{ha}^{-1}$ year $^{-1}$ ) was among the highest reported for European watersheds (Vagstad and others 2004; Hou and others 2015; Lassaletta and others 2016; Poisvert and others 2017) and suggested a condition of potential pollution for aquatic ecosystems. Nitrogen use efficiency, that is, the proportion of all $\mathrm{N}$ inputs removed from arable lands via crop harvest, reached about $60 \%$, which is higher than the values obtained for other agricultural sub-basins of the Po River system, such as Oglio and Mincio rivers (range 35-50\%) (Viaroli and others 2018; Racchetti and others 2019; Pinardi and others 2020). The difference lies in the prevalent use, in the basin studied here, of synthetic fertilizers, more accurately dosable than manure, prevalently used in the Oglio and Mincio basins, whose excess may generate greater losses to

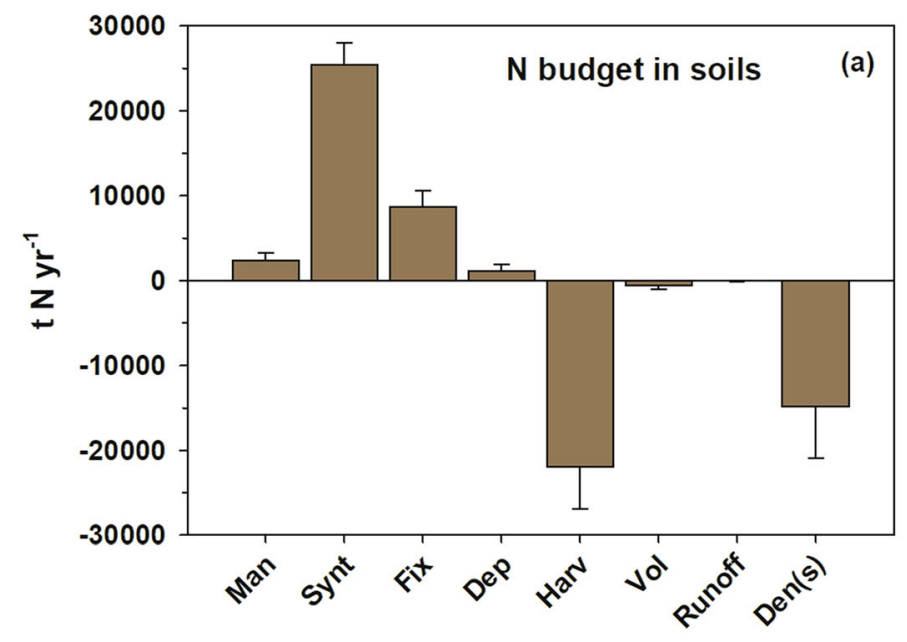

Figure 6. Nitrogen budget ( $\mathrm{t} \mathrm{N}$ year $^{-1}$ ) in soils (a) and canal network (b) of the Burana-Volano-Navigabile watershed (average \pm standard deviation of the 5-year period 2006-2010). N input to soils: livestock manure (Man), synthetic fertilizers (Synt), biological fixation (Fix), and atmospheric deposition (Dep). N output from soils: crop harvest (Harv), ammonia volatilization ( $\mathrm{Vol}$ ), and denitrification (Den(s)). $\mathrm{N}$ input to the canal network: $\mathrm{N}$ load imported by the canal network (Inflow), N load generated in urban areas (Urb), deposition on urban areas (Dep_Urb), N load generated in industrial areas (Ind), and $\mathrm{N}$ lost from agricultural soils to surface water via runoff (Runoff). $\mathrm{N}$ output from the canal network: $\mathrm{N}$ load exported from the basin (Outflow), and $\mathrm{N}$ removed by denitrification in the canal sediments (Den(c)). Note the different $y$-scale for the two panels. 
surface and groundwater (Severini and others 2020). However, although the distribution of synthetic fertilizers allows crop demand to be met more accurately, owing to their rapid dissolution and transformations in soils (Castaldelli and others 2018), it may increase the risk of lateral or vertical $\mathrm{NO}_{3}{ }^{-}$transport. As the study basin is a completely flat territory with a surface slope mostly less than $0.05 \%$, the fraction of $\mathrm{N}$ excess reaching the canal network via surface runoff resulted in a negligible term of the $\mathrm{N}$ budget along the terrestrial-freshwater continuum. This is coherent to the outcomes of runoff modeling that have previously estimated a $\mathrm{N}$ loss of on average about $3 \mathrm{~kg} \mathrm{~N} \mathrm{ha}^{-1}$ year $^{-1}$ for the investigated basin (Aschonitis and others 2013). On the other hand, in these conditions, vertical transport through the vadose zone may be predominant, and the aquifer is exposed to a high risk of $\mathrm{NO}_{3}{ }^{-}$pollution.

\section{Relationships between N Inputs in Soils and N Export to the Coastal Zone}

On an annual basis, the Burana-Volano-Navigabile watershed exports to the coastal zone an $\mathrm{N}$ load that almost doubles the load entering in the canal network from the Po River and the basins located upstream. This increase $\left(\sim 440 \mathrm{t} \mathrm{N}\right.$ year $\left.^{-1}\right)$ represents less than $3 \%$ of the missing $\mathrm{N}$ in soils $\left(\sim 14,800 \mathrm{t} \mathrm{N} \mathrm{year}^{-1}\right)$ and could be explained by urban point sources. Moreover, the canal network acted as an effective $\mathrm{N}$ sink in the spring-summer months when a relevant portion $(\sim 32 \%$ along the whole irrigation period, from April to September) of the $\mathrm{N}$ load, generated by upstream agroecosystems and imported with irrigation water, was removed by denitrification at the sediment level, protecting the coastal area, when the risk of eutrophication is higher. Drainage canals, at present, are almost completely unvegetated, and the adoption of more conservative management practices to restore emergent macrophytes would contribute to a further increase in the denitrification potential. Studies done in the same hydrological network have evidenced a tenfold increase of the $\mathrm{N}$ removal via denitrification in the presence of emergent vegetation, such as Phragmites australis and Typha latifolia, compared with unvegetated canals (Pierobon and others 2013; Soana and others 2019).

The annual $\mathrm{N}$ export to the coastal zone corresponds to nearly $3 \%$ of the total $\mathrm{N}$ input generated in the agroecosystems, a value that is much lower than the range $(7-20 \%)$ reported for other agricultural sub-basins of the Po Plain (Bartoli and others 2012; Pinardi and others 2020) and for the same Po River Basin as a whole (Viaroli and others 2018). Nevertheless, a high retention capacity may be due to both permanent and temporary removal processes, such as denitrification in soils and storage in the vadose zone-groundwater system. This is what has been evidenced in other Po River subbasins, where a combination of $\mathrm{N}$ excess, mainly due to manure spreading, and flood-based irrigation practices over permeable coarse soils, promoted $\mathrm{NO}_{3}{ }^{-}$leaching and accumulation into groundwater (Musacchio and others 2020; Racchetti and others 2019). Differently, for the Burana-Volano-Navigabile, a ubiquitous and constant scarcity of inorganic $\mathrm{N}$ forms has been evidenced not only in the shallow aquifer, as reported here, but also in surficial soils where only $\mathrm{NO}_{3}{ }^{-}$was found in the range of $10-35 \mathrm{~kg} \mathrm{~N} \mathrm{ha}^{-1}$ year $^{-1}$ as demonstrated by extensive monitoring campaigns (Castaldelli and others 2013a; Mastrocicco and others 2019b).

For the dominant soil textures, silty-loam and silty-clay, covering more than two-thirds of the arable land surface and intensively fertilized mainly with synthetic urea, organic matter content is on average less than 3\% (Castaldelli and others 2013a). Thus, the contribution of $\mathrm{N}$ storage in soil organic matter is likely irrelevant in the investigated basin. Here, the supply of organic matter in the form of manure is low because of low livestock density, and only sandy soils, covering less than $10 \%$ of the territory, are amended with chicken manure whose mineralization is very fast. In the deltaic portion of the Po River lowlands, livestock density underwent a constant decline in the last four decades (Viaroli and others 2018); thus, in the long term, negligible organic fertilization promoted the depletion of soil organic pools (Natali and others 2018). These outcomes indicate that soil and groundwater storage is unlikely to explain the discrepancy between $\mathrm{N}$ input and output in agricultural land. On the contrary, this evidence, together with the multiple terms accounted in the $\mathrm{N}$ budget, strongly supports the hypothesis that the large missing $N$ has been permanently removed from the system via soil denitrification.

\section{The Role of Soil Denitrification as N Sink in Agricultural Watersheds}

In soils, the simultaneous presence of hypoxic/anoxic conditions, $\mathrm{NO}_{3}{ }^{-}$, and labile organic carbon availability are triggering conditions for the anaerobic respiration of $\mathrm{NO}_{3}{ }^{-}$by heterotrophic denitrifying bacteria (Tiedje 1988; Wallenstein and others 
2006). By affecting redox status, soil water content is considered a key driver for $\mathrm{N}$ removal via denitrification, and the chance for creating anoxic microsites is higher in soils with high porosity, deadend pores, and greater water retention (clayey and loamy soils) than in more permeable coarsely textured soils (Barton and others 1999; Barakat and others 2016). Thus, in the Burana-Volano-Navigabile watershed, characterized by soils with fine textures, denitrification may find suitable conditions due to very low hydraulic conductivity, flat topography, and shallow water tables, all features that, in the occasion of intense rainfall, promote the establishment of waterlogged conditions and, consequently, oxygen shortage (Mastrocicco and others 2013, 2017).

In temperate regions, agricultural soils are commonly characterized by hypoxic conditions since they remain generally wet along the winter-spring months and, in the case of water table proximal to the ground surface, as in the studied basin, occasionally completely waterlogged after heavy rainfalls. These represent the moments of potentially higher $\mathrm{N}$ loss via denitrification due to $\mathrm{NO}_{3}{ }^{-}$ accumulation in soil solution when crop residues are degraded by soil microorganisms or after fertilizer applications that are usually performed in coverage for the most $\mathrm{N}$-demanding crops (for example, wheat and maize). The present findings are in full agreement with multiple pieces of evidence from laboratory studies, performed in the same soils, which indicated high $\mathrm{NO}_{3}{ }^{-}$consumption and correspondent $\mathrm{N}_{2}$ production in mesocosms under water-saturated conditions (Mastrocicco and others 2011, 2019a; Castaldelli and others 2019). Nitrate reduction could be also due to pyrite oxidation that could concur to remove excess $\mathrm{NO}_{3}{ }^{-}$in reducing environments low in organic carbon substrates (Jessen and others 2017). Moreover, dissimilative $\mathrm{NO}_{3}{ }^{-}$reduction to ammonium cannot be excluded as a relevant process contributing to $\mathrm{NO}_{3}{ }^{-}$removal in organic-rich sediments such as rice fields (Putz and others 2018; Pandey and others 2019), though covering less than $10 \%$ of total agricultural land in the basin. The present outcomes are consistent with preliminary estimates of basin-scale $\mathrm{N}$ budget in the deltaic portion of the Po River highlighting an average unaccounted term of about $70 \mathrm{~kg} \mathrm{~N} \mathrm{ha}^{-1}$ year $^{-1}$ likely attributable to soil denitrification (Castaldelli and others 2020). The investigated basin encompasses all the representative soil types and crop types of the Po River lowlands; thus, the findings and the developed approach can be easily exported to other watersheds with similar features and cli- mates in the Mediterranean area, Europe, or worldwide.

Labile organic carbon availability is a key factor supporting the denitrifying capacity and its role in protecting groundwater from diffuse $\mathrm{NO}_{3}{ }^{-}$pollution. The presence of low-molecular-weight organic acids such as acetate was demonstrated to deeply affect $\mathrm{NO}_{3}{ }^{-}$persistence in fertilized soils with high acetate concentrations corresponding to very low $\mathrm{NO}_{3}{ }^{-}$content (Castaldelli and others $2013 \mathrm{~b})$. In the investigated soils, organic acids originating from the decomposition of crop residues and from root exudates represent often the only organic inputs, since amendment with manure is scarce. This stresses the need to adopt agronomic practices that maintain sufficient organic matter in soils to sustain their intrinsic buffer capacity against $\mathrm{NO}_{3}{ }^{-}$pollution.

Areal denitrification rate, calculated here by mass balance, at the basin scale on average about $80 \mathrm{~kg} \mathrm{~N} \mathrm{ha}^{-1}$ year $^{-1}$, was higher than the literature values measured in fine-textured fertilized soils during the growth period of annual crops, generally never exceeding $50 \mathrm{~kg} \mathrm{~N} \mathrm{ha}^{-1}$ year $^{-1}$ and in most cases within the range of 20$30 \mathrm{~kg} \mathrm{~N} \mathrm{ha}^{-1}$ year $^{-1}$ (Nieder and others 1989; Barton and others 1999; Hofstra and Bouwman 2005). Measurements performed with sufficient intensity in time and space to obtain robust estimates at the annual scale, that is, the temporal scale at which $\mathrm{N}$ budgets are generally calculated in watersheds, are still lacking. Denitrification remains one of the least well-quantified processes of $\mathrm{N}$ cycling in soils owing to the difficulty of quantifying it accurately by capturing its high spatial and temporal variability (Groffman and others 2009; Anderson and others 2014).

In the present study, $\mathrm{N}$ budget relays on robust datasets acquired in the study area, such as highresolution crop maps, agricultural statistics, and site-specific agronomic coefficients validated by expert judgment. In such a system where all $\mathrm{N}$ flows and pools have been identified and accounted for, the mass balance can be successful in providing quantitative estimates of soil denitrification at the basin level, further improved since multiple years of data were used and averaged. Being calculated as a residual term, that is, the unaccounted complement of the $\mathrm{N}$ balance, denitrification estimate suffers from an uncertainty resulting from the uncertainty in the input data and parameters employed to compute each component of the balance. Previous studies demonstrated that atmospheric deposition and ammonia volatilization are generally among the most uncertain terms, and estimates 
of $\mathrm{N}$ losses are less accurate than inputs via fertilizers and manure (Oenema and others 2003; Zhang and others 2020). Similar outcomes were obtained here, where the coefficients of variation of these terms were among the highest ( $>70 \%$ ). However, atmospheric deposition and ammonia volatilization were minor terms, accounting for only $3 \%$ of the total inputs and output, respectively.

Locally derived measurements of $\mathrm{N}$ fluxes were also sources of uncertainty for the $\mathrm{N}$ budget along the terrestrial-freshwater continuum. Denitrification rates in canal sediments were measured in several canals representative of the dominant waterways. Reach-scale biogeochemical methods were applied integrating $\mathrm{N}$ processes occurring in multiple compartments (that is, water, sediment, vegetation, and biofilms) under natural conditions and overcoming the limits inherent in the extension of laboratory experiment outcomes to the broader scale (Soana and others 2019). Uncertainty exists in extending denitrification measures from the reach scale to landscape scale, as a consequence of the spatial and temporal heterogeneity of hydrological, geomorphological, and biological drivers that affect biogeochemical reactions. Nevertheless, despite the coefficient of variation being more than $50 \%$, this $\mathrm{N}$ flux accounted overall for less than $5 \%$ of the missing $\mathrm{N}$ in the basin. The present analysis certainly has weaknesses that might, of course, be improved in the future, but it is a step rarely done at this scale with a combination of datasets and measurements allowing us to account for all $\mathrm{N}$ flows in the basin.

In conclusion, the present study strongly indicated that, under temperate subhumid climates, soil denitrification may be a relevant $\mathrm{N}$ sink in agricultural basins heavily fertilized and with finetexture soils, prone to waterlogged conditions. Holistic approaches such as detailed watershed $\mathrm{N}$ budget, although data demanding, allow us to infer a crucial process such as soil denitrification that is, at present, still difficult to measure owing to inadequate techniques and high intrinsic variability in space and time. Future works will require accurate characterization of the seasonal trends of denitrification activity to fully prove its role in explaining the fate of missing $\mathrm{N}$ in lowland agricultural basins.

\section{ACKNOWLEDGEMENTS}

This research was funded by the Emilia-Romagna Region within the Rural Development Programme (PSR) 2014-2020 (Measure 16.1.01-Operational Groups of the European Partnership for Agricultural Productivity and Sustainability), Project Fer- rara Nitrates-Agricultural techniques to prevent nitrates pollution and the organic matter conservation (https://ec.europa.eu/eip/agriculture/en/fin d-connect/projects/nitrati-ferrara-tecniche-agrono miche-la). The authors thank the Presidents, Dr. Stefano Calderoni and Dr. Franco Dalle Vacche, and the Director, Dr. Eng. Mauro Monti, of the Ferrara Land Reclamation Consortium, and the Emilia-Romagna Agency for Environmental Protection for the kind and profitable collaboration and for having provided water flow data and water quality data, respectively.

\section{FUNDING}

Open access funding provided by Università degli Studi di Ferrara within the CRUI-CARE Agreement.

\section{OPEN ACCESS}

This article is licensed under a Creative Commons Attribution 4.0 International License, which permits use, sharing, adaptation, distribution and reproduction in any medium or format, as long as you give appropriate credit to the original author(s) and the source, provide a link to the Creative Commons licence, and indicate if changes were made. The images or other third party material in this article are included in the article's Creative Commons licence, unless indicated otherwise in a credit line to the material. If material is not included in the article's Creative Commons licence and your intended use is not permitted by statutory regulation or exceeds the permitted use, you will need to obtain permission directly from the copyright holder. To view a copy of this licence, visit $h$ ttp://creativecommons.org/licenses/by/4.0/.

\section{REFERENCES}

Almaraz M, Wong MY, Yang WH. 2019. Looking back to look ahead: a vision for soil denitrification research. Ecology $101(1): \mathrm{e} 02917$.

Anderson TR, Goodale CL, Groffman PM, Walter MT. 2014. Assessing denitrification from seasonally saturated soils in an agricultural landscape. A farm-scale mass-balance approach. Agriculture Ecosystems \& Environment 189:60-69.

Armstrong FAJ, Sterus CR, Strickland JDH. 1967. The measurement of upwelling and subsequent biological to be processed by means of the Technicon AutoAnalyzer and associated equipment. Deep-Sea Research 14:381-389.

Aschonitis VG, Salemi E, Colombani N, Castaldelli G, Mastrocicco M. 2013. Formulation of indices to describe intrinsic nitrogen transformation rates for the implementation of best 
management practices in agricultural lands. Water, Air \& Soil Pollution 224(3): 1489.

Ascott MJ, Gooddy DC, Wang L, Stuart ME, Lewis MA, Ward RS, Binley AM. 2017. Global patterns of nitrate storage in the vadose zone. Nature Communications 8(1):1416.

Barakat M, Cheviron B, Angulo-Jaramillo R. 2016. Influence of the irrigation technique and strategies on the nitrogen cycle and budget: a review. Agricultural Water Management 178:225-238.

Bartoli M, Racchetti E, Delconte CA, Sacchi E, Soana E, Laini A, Longhi D, Viaroli P. 2012. Nitrogen balance and fate in a heavily impacted watershed (Oglio River, Northern Italy): in quest of the missing sources and sinks. Biogeosciences 9(1):361-373

Barton L, McLay CDA, Schipper LA, Smith CT. 1999. Annual denitrification rates in agricultural and forest soils: a review. Soil Research 37(6):1073-1094.

Beck HE, Zimmermann NE, McVicar TR, Vergopolan N, Berg A, Wood EF. 2018. Present and future Köppen-Geiger climate classification maps at $1-\mathrm{km}$ resolution. Scientific Data 5:180214.

Bodirsky BL, Popp A, Lotze-Campen H, Dietrich JP, Rolinski S, Weindl I, et al. 2014. Reactive nitrogen requirements to feed the world in 2050 and potential to mitigate nitrogen pollution. Nature Communications 5(1):1-7.

Bosch J, Lee KY, Jordan G, Kim KW, Meckenstock RU. 2012. Anaerobic, nitrate-dependent oxidation of pyrite nanoparticles by Thiobacillus denitrificans. Environmental Science and Technology 46:2095-2101.

Bouwman AF, Beusen AHW, Griffioen J, Van Groenigen JW, Hefting MM, Oenema O, et al. 2013. Global trends and uncertainties in terrestrial denitrification and $\mathrm{N}_{2} \mathrm{O}$ emissions. Philosophical Transactions of the Royal Society B Biological Sciences 368(1621):20130112.

Castaldelli G, Soana E, Racchetti E, Pierobon E, Mastrocicco M, Tesini E, Fano EA, Bartoli M. 2013a. Nitrogen budget in a lowland coastal area within the Po river basin (Northern Italy): multiple evidences of equilibrium between sources and internal sinks. Environmental Management 52(3):567-580.

Castaldelli G, Colombani N, Vincenzi F, Mastrocicco M. 2013b. Linking dissolved organic carbon, acetate and denitrification in agricultural soils. Environmental Earth Sciences 68(4):939945.

Castaldelli G, Colombani N, Tamburini E, Vincenzi F, Mastrocicco M. 2018. Soil type and microclimatic conditions as drivers of urea transformation kinetics in maize plots. Catena 166:200-208.

Castaldelli G, Colombani N, Soana E, Vincenzi F, Fano EA, Mastrocicco M. 2019. Reactive nitrogen losses via denitrification assessed in saturated agricultural soils. Geoderma 337:91-98.

Castaldelli G, Vincenzi F, Fano EA, Soana E. 2020. In search for the missing nitrogen: closing the budget to assess the role of denitrification in agricultural watersheds. Applied Sciences $10(6): 2136$

Cencini C. 1999. Physical processes and human activities in the evolution of the Po Delta, Italy. Journal of Coastal Research 14(3):774-793.

Chalk PM, Inácio CT, Chen D. 2019. An overview of contemporary advances in the usage of ${ }^{15} \mathrm{~N}$ natural abundance $\left(\delta^{15} \mathrm{~N}\right)$ as a tracer of agroecosystem $\mathrm{N}$ cycle processes that impact the environment. Agriculture Ecosystems \& Environment 283:106570.

Davidson EA, Seitzinger S. 2006. The enigma of progress in denitrification research. Ecological Applications 16(6):20572063.

De Girolamo AM, Spanò M, D'Ambrosio E, Ricci GF, Gentile F. 2019. Developing a nitrogen load apportionment tool: theory and application. Agricultural Water Management 226:105806.

Dollinger J, Dagès C, Bailly JS, Lagacherie P, Voltz M. 2015. Managing ditches for agroecological engineering of landscape. A review. Agronomy for Sustainable Development 35(3):9991020 .

Erisman JW, Galloway J, Seitzinger S, Bleeker A, ButterbachBahl K. 2011. Reactive nitrogen in the environment and its effect on climate change. Current Opinion in Environmental Sustainability 3(5):281-290.

EUROSTAT - European Commission. Regions in the European Union. 2015. Nomenclature of territorial units for statistics NUTS 2013/EU-28. Manuals and guidelines. Luxemburgo, Publications Office of the European Union. http://ec.europa.e u/eurostat/web/products-manuals-and-guidelines/-/KS-GQ- 1 4-006

Glibert PM, Harrison J, Heil C, Seitzinger S. 2006. Escalating worldwide use of urea-a global change contributing to coastal eutrophication. Biogeochemistry 77(3):441-463.

Goeller BC, Febria CM, McKergow LA, Harding JS, Matheson FE, Tanner CC, McIntosh AR. 2020. Combining tools from edge-of-field to in-stream to attenuate reactive nitrogen along small agricultural waterways. Water 12(2):383.

Goyette JO, Bennett EM, Howarth RW, Maranger R. 2016. Changes in anthropogenic nitrogen and phosphorus inputs to the St. Lawrence sub-basin over 110 years and impacts on riverine export. Global Biogeochemical Cycles 30(7):10001014.

Groffman PM, Butterbach-Bahl K, Fulweiler RW, Gold AJ, Morse JL, Stander EK, et al. 2009. Challenges to incorporating spatially and temporally explicit phenomena (hotspots and hot moments) in denitrification models. Biogeochemistry 93(1-2):49-77.

Hofstra N, Bouwman AF. 2005. Denitrification in agricultural soils: summarizing published data and estimating global annual rates. Nutrient Cycling in Agroecosystems 72(3):267278.

Hou Y, Ma L, Sárdi K, Sisák I, Ma W. 2015. Nitrogen flows in the food production chain of Hungary over the period 1961-2010. Nutrient Cycling in Agroecosystems 102(3):335-346.

Houlton BZ, Almaraz M, Aneja V, Austin AT, Bai E, Cassman KG, et al. 2019. A world of cobenefits: solving the global nitrogen challenge. Earth's Future 7(8):865-872.

Howarth R, Swaney D, Billen G, Garnier J, Hong B, Humborg C, et al. 2012. Nitrogen fluxes from the landscape are controlled by net anthropogenic nitrogen inputs and by climate. Frontiers in Ecology and the Environment 10(1):37-43.

IUSS Working Group WRB. 2006. World reference base for soil resources. World Soil Resources Reports No. 103. FAO, Rome

Jessen S, Postma D, Thorling L, Müller S, Leskelä J, Engesgaard P. 2017. Decadal variations in groundwater quality: a legacy from nitrate leaching and denitrification by pyrite in a sandy aquifer. Water Resources Research 53(1):184-198.

Kolbe T, De Dreuzy JR, Abbott BW, Aquilina L, Babey T, Green CT, et al. 2019. Stratification of reactivity determines nitrate removal in groundwater. PNAS. 116(7):2494-2499. 
Kulkarni MV, Groffman PM, Yavitt JB. 2008. Solving the global nitrogen problem: it's a gas! Frontiers in Ecology and the Environment 6(4):199-206.

Kuzyakov Y, Blagodatskaya E. 2015. Microbial hotspots and hot moments in soil: concept $\&$ review. Soil Biology \& Biochemistry 83:184-199.

Lassaletta L, Billen G, Garnier J, Bouwman L, Velazquez E, Mueller ND, Gerber JS. 2016. Nitrogen use in the global food system: past trends and future trajectories of agronomic performance, pollution, trade, and dietary demand. Environmental Research Letters 11(9):095007.

Leip A, Billen G, Garnier J, Grizzetti B, Lassaletta L, Reis S, et al. 2015. Impacts of European livestock production: nitrogen, sulphur, phosphorus and greenhouse gas emissions, land-use, water eutrophication and biodiversity. Environmental Research Letters 10(11):115004.

Malagó A, Bouraoui F, Grizzetti B, De Roo A. 2019. Modelling nutrient fluxes into the Mediterranean Sea. Journal of Hydrology: Regional Studies 22:100592.

Martinelli G, Dadomo A, De Luca DA, Mazzola M, Lasagna M, Pennisi M, Sacchi E, Saccon P. 2018. Nitrate sources, accumulation and reduction in groundwater from Northern Italy: insights provided by a nitrate and boron isotopic database. Applied Geochemistry 91:23-35.

Mastrocicco M, Colombani N, Salemi E, Castaldelli G. 2011. Reactive modeling of denitrification in soils with natural and depleted organic matter. Water, Air, \& Soil Pollution 222(1):205-215.

Mastrocicco M, Giambastiani BMS, Colombani N. 2013. Ammonium occurrence in a salinized lowland coastal aquifer (Ferrara, Italy). Hydrological Processes 27(24):3495-3501.

Mastrocicco M, Di Giuseppe D, Vincenzi F, Colombani N, Castaldelli G. 2017. Chlorate origin and fate in shallow groundwater below agricultural landscapes. Environmental Pollution 231:1453-1462.

Mastrocicco M, Colombani N, Castaldelli G. 2019a. Direct measurement of dissolved dinitrogen to refine reactive modelling of denitrification in agricultural soils. Science of the Total Environment 647:134-140.

Mastrocicco M, Colombani N, Vincenzi F, Castaldelli G. 2019b. Complex interactions between fertilizers and subsoils triggering reactive nitrogen speciation in lowlands. In Advances in Sustainable and Environmental Hydrology, Hydrogeology, Hydrochemistry and Water Resources. Chaminé H, Barbieri M, Kisi O, Chen M, Merkel B, Eds., CAJG 2018. Advances in Science, Technology \& Innovation (IEREK Interdisciplinary Series for Sustainable Development). Springer, Cham, pp. 133-135

Musacchio A, Re V, Mas-Pla J, Sacchi E. 2020. EU Nitrates Directive, from theory to practice: environmental effectiveness and influence of regional governance on its performance. Ambio 49(2):504-516.

Natali C, Bianchini G, Antisari LV, Natale M, Tessari U. 2018. Carbon and nitrogen pools in Padanian soils (Italy): origin and dynamics of soil organic matter. Geochemistry 78(4):490-499.

Nieder R, Schollmayer G, Richter J. 1989. Denitrification in the rooting zone of cropped soils with regard to methodology and climate. Biology and Fertility of Soils 8(3):219-226.

Oehler F, Durand P, Bordenave P, Saadi Z, Salmon-Monviola J. 2009. Modelling denitrification at the catchment scale. Science of the Total Environment 407(5):1726-1737.
Oenema O, Kros H, de Vries W. 2003. Approaches and uncertainties in nutrient budgets: implications for nutrient management and environmental policies. European Journal of Agronomy 20(1-2):3-16.

Pandey A, Suter H, He JZ, Hu HW, Chen D. 2019. Dissimilatory nitrate reduction to ammonium dominates nitrate reduction in long-term low nitrogen fertilized rice paddies. Soil Biology \& Biochemistry 131:149-156.

Pierobon E, Castaldelli G, Mantovani S, Vincenzi F, Fano EA. 2013. Nitrogen removal in vegetated and unvegetated drainage ditches impacted by diffuse and point sources of pollution. Clean-Soil, Air, Water 41(1):24-31.

Pinardi M, Soana E, Bresciani M, Villa P, Bartoli M. 2020. Upscaling nitrogen removal processes in fluvial wetlands and irrigation canals in a patchy agricultural watershed. Wetlands Ecology and Management. 28:297-313.

Poisvert C, Curie F, Moatar F. 2017. Annual agricultural N surplus in France over a 70-year period. Nutrient Cycling in Agroecosystems 107(1):63-78.

Putz M, Schleusner P, Rütting T, Hallin S. 2018. Relative abundance of denitrifying and DNRA bacteria and their activity determine nitrogen retention or loss in agricultural soil. Soil Biology \& Biochemistry 123:97-104.

Racchetti E, Salmaso F, Pinardi M, Quadroni S, Soana E, Sacchi E, et al. 2019. Is flood irrigation a potential driver of rivergroundwater interactions and diffuse nitrate pollution in agricultural watersheds? Water 11(11):2304.

Romero E, Garnier J, Billen G, Peters F, Lassaletta L. 2016. Water management practices exacerbate nitrogen retention in Mediterranean catchments. Science of the Total Environment 573:420-432.

Severini E, Bartoli M, Pinardi M, Celico F. 2020. Reactive silica traces manure spreading in alluvial aquifers affected by nitrate contamination: a case study in a high plain of Northern Italy. Water 12(9):2511.

Soana E, Bartoli M, Milardi M, Fano EA, Castaldelli G. 2019. An ounce of prevention is worth a pound of cure: managing macrophytes for nitrate mitigation in irrigated agricultural watersheds. Science of the Total Environment 647:301-312.

Tiedje JM. 1988. Ecology of denitrification and dissimilatory nitrate reduction to ammonium. In Biology of anaerobic microorganisms, Zehnder A.J.B. Eds., Wiley and Sons, New York, pp. 179-244

Vagstad N, Stålnacke P, Andersen HE, Deelstra J, Jansons V, Kyllmar K, Loigu E, Rekolainen S, Tumas R. 2004. Regional variations in diffuse nitrogen losses from agriculture in the Nordic and Baltic regions. Hydrology and Earth System Sciences 8(4):651-662.

Van Meter KJ, Basu NB, Veenstra JJ, Burras CL. 2016. The nitrogen legacy: emerging evidence of nitrogen accumulation in anthropogenic landscapes. Environmental Research Letters 11(3):035014.

Viaroli P, Soana E, Pecora S, Laini A, Naldi M, Fano EA, Nizzoli D. 2018. Space and time variations of watershed $\mathrm{N}$ and $\mathrm{P}$ budgets and their relationships with reactive $\mathrm{N}$ and $\mathrm{P}$ loadings in a heavily impacted river basin (Po river, Northern Italy). Science of the Total Environment 639:1574-1587.

Wallenstein MD, Myrold DD, Firestone M, Voytek M. 2006. Environmental controls on denitrifying communities and denitrification rates: insights from molecular methods. Ecological Applications 16(6):2143-2152. 
Wang C, Houlton BZ, Dai W, Bai E. 2017. Growth in the global $\mathrm{N}_{2}$ sink attributed to $\mathrm{N}$ fertilizer inputs over 1860 to 2000 . Science of the Total Environment 2017(574):1044-1053.

World Heath Organization - WHO. 2004. Guidelines for Drinking Water Quality (third ed.). Geneva

Xin J, Liu Y, Chen F, Duan Y, Wei G, Zheng X, Li M. 2019. The missing nitrogen pieces: a critical review on the distribution, transformation, and budget of nitrogen in the vadose zonegroundwater system. Water Research 165:114977.

Zhang X, Davidson EA, Zou T, Lassaletta L, Quan Z, Li T, Zhang W. 2020. Quantifying nutrient budgets for sustainable nutrient management. Global Biogeochemical Cycles 34(3) 